\title{
'Sine amore, sine odio partium': Nicolaus Burgundius' Historia Belgica (1629) and his Tacitean Quest for an Appropriate Past
}

\author{
Marc Laureys
}

From the 16th century onwards, Tacitus drew ever more attention for the help he could provide in coming to terms with the various turbulences and upheavals of the early modern age. Humanist scholars, such as Marcus Antonius Muretus and Justus Lipsius, observed a striking resemblance between the politics of the early principate, narrated by Tacitus, and their own times. For 16 thand 17th-century readers of Tacitus the turmoils, machinations and rebellions he evoked looked very familiar. This avowed similarity carried further implications. The historical constellations described by Tacitus could serve as a reference framework to interpret and legitimate contemporary political events, circumstances and developments. In order to understand the present, the history depicted by Tacitus could be adduced as an appropriate past.

In this context Tacitus exerted a double influence. In the field of political theory and philosophy he was a source of inspiration for a variety of political currents and theories, supporting either republican or princely rule. In terms of language and style, moreover, Tacitus offered a standard that was felt to be perfectly suitable to the political discourse of early modern times, not least in the political communication between a ruler and the advisors and attendants in his court. Tacitus was advanced - most prominently by Justus Lipsius - as a model author who perfectly illustrated the techniques of simulatio and dissimulatio (Tacitus, Annales, 4, 71, 3) as well as the characteristics of the imperatoria brevitas' (Tacitus, Historiae, 1, 18, 2).

The Low Countries, torn apart in the 16 th century by political and religious conflicts, provided ample opportunities for observation and analysis through a Tacitean framework. Tacitus' description (in Books 4 and 5 of his Historiae) of the Batavian uprising, led by Julius Civilis, against Rome almost invited comparison with the Dutch Revolt. The rebellion of the northern provinces of the Low Countries against Spanish rule, was from the very beginning observed and recorded by humanist literati, diplomats, and merchants from various parts of

(C) MARC LAUREYS, 2019 | DOI:10.1163/9789004378216_017

This is an open access chapter distributed under the terms of the prevailing CC-BY-NC-ND License 
Europe, far beyond the borders of the theatre of operations itself. ${ }^{1}$ The international relevance of this episode in early modern history was immediately perceived: At stake were the aspirations of the Habsburg sovereigns to universal monarchy, thwarted by a small nation which struggled for freedom and opposed Habsburg supremacy. ${ }^{2}$ The Dutch Revolt inspired political lessons and comparisons until at least the 1 th $^{\text {th }}$ century. ${ }^{3}$

Tacitus' historiography lent itself to varied interpretations. Supporters of Dutch independence and defenders of imperial rule both managed to connect with Tacitus's works; Tacitus's œuvre could thus be exploited as a setting that suggested either granting or denying legitimacy to the Revolt. In this paper I will examine the Historia Belgica, an account of the earliest phase of the Revolt, composed by Nicolaus Burgundius, the last Catholic historiographer, who prior to the peace treaty of Münster (1648) dealt with the rebellion of the northern provinces of the Low Countries against the Spanish Crown. I intend to assess Burgundius's stylistic and thematic appropriation of Tacitus and would like to show that the 'Tacitist' qualities of his historical writing are to be

1 Anton van der Lem's superb website De bello Belgico (http://www.dutchrevolt.leiden.edu, retrieved 8th August 2017) offers excellent guidance on all the facts, sources, and contexts of the Revolt; it is an essential complement to his succinct survey De Opstand in de Nederlanden, 1568-1648. De Tachtigjarige Oorlog in woord en beeld (Nijmegen: 2014). Not only authors from the Low Countries wrote about the Dutch Revolt; its history attracted much attention, naturally, in Spain, but in various other countries as well. Notable accounts of the Revolt composed by "foreign" diplomats and historians include, e.g., Bernardino de Mendoza's Commentaires memorables des guerres de Flandres et Pays Bas depuis l'an 1567 jusques a l'an 1577 (1591), Famiano Strada's De bello Belgico decades duae (1651; separate editions of the first and the second decade in 1632 and 1647 resp.), Guido Bentivoglio's Della guerra di Fiandra (1632). The Revolt is also a prominent topic in Jacques-Auguste de Thou's Historiae sui temporis (1604, with later additions down to the posthumous edition of 1620 ). In addition, many works were translated into other languages for different audiences. Nonetheless, the international perception of the Dutch Revolt remains relatively little studied to date. For the perception of the Revolt in Spain see Rodríguez Pérez Y., De Tachtigjarige oorlog in Spaanse ogen. De Nederlanden in Spaanse historische en literaire teksten (circa 1548-1673) (Nijmegen: 2003); the perspective of British contemporaries is examined by Dunthorne H., Britain and the Dutch Revolt, 1560-1700 (Cambridge: 2013).

2 Romein J., "Spieghel Historiael van de Tachtigjarige Oorlog", in Presser J. e.a., De Tachtigjarige Oorlog, vierde druk (Amsterdam - Brussel: 1963) 11-54, at 18 [first published in 1941, without the name of the main author and editor].

3 Pollmann J., "Internationalisering en de Nederlandse Opstand", Bijdragen en Mededelingen betreffende de Geschiedenis der Nederlanden 124 (2009) 515-535, at 515-516. Particularly in recent times, though, several specialists of social, economic, religious and intellectual history have significantly corrected the traditional and one-dimensional image of the Revolt as the political struggle for freedom of what would become the Dutch republic. 
found at the junction of the literary and political dimension of his work, in the way he devises a political rhetoric in a Tacitean mode.

In the European panorama of historiography surrounding the Revolt, Nicolaus Burgundius (Nicolas de Bourgogne, 1586-1649) takes a sort of middle position: On the one hand, he claimed to write for an international audience, dedicated his work to a foreign ruler, and published it abroad, on the other he clearly positioned himself on the Catholic side, as one would expect from an author, born and educated in the Southern Low Countries. ${ }^{4}$ Born in Enghien (southwest of Brussels, in the county of Hainaut), he was a student of Erycius Puteanus, Justus Lipsius' successor, at the University of Louvain and took part in Puteanus' "academy", the Palaestra bonae mentis, ${ }^{5}$ during the years around 1610. Thereafter he worked as a lawyer in Ghent, and in 1627 he was appointed Professor of Law in Ingolstadt; in 1633 he also became counsellor and historian in the service of Maximilian I, Duke of Bavaria and Prince-Elector of the Holy Roman Empire. ${ }^{6}$ In 1639 he returned to the Low Countries and took up a position as a councillor in the Council of Brabant (Raad van Brabant), the highest court in the county of Brabant.

In 1629, two years after his move to Ingolstadt, Burgundius published there his Historia Belgica ab anno MDLVIII, 7 devoted to the years $155^{8-1567}$, the

4 For a short bio-bibliographical profile see Paquot J.-N., Mémoires pour server à l'histoire littéraire des dix-sept provinces des Pays-Bas, de la principauté de Liège, et de quelques contrées voisines, vol. I (Louvain: 1765) 97-98, Britz J., "Bourgogne (Nicolas de)", in Biographie Nationale de Belgique 2 (Brussels: 1868) 852-857, and van der Lem A., "Burgundius, Nicolaus" (2012) at http://www.dutchrevolt.leiden.edu/dutch/geschiedschrijvers/Pages/burgundius.aspx (retrieved 8th August 2017).

5 For this peculiar institution see Simar Th., Étude sur Erycius Puteanus (1574-1646) considéré spécialement dans l'histoire de la philologie belge et dans son enseignement à l'université de Louvain (Louvain: 1909) 143-152. Nicolaus Burgundius was one of the star pupils of Puteanus' Palaestra bonae mentis, but became embroiled in a conflict with his former teacher in the 1620s; see Simar, Puteanus $155^{-156}$, and Steyaert F., "Puteanus criticized by a former student: Nicolaus Burgundius", Lias 3 (1976) 131-138.

6 For Burgundius's writings as court historian, and especially his Historia Bavarica, see Kagerer $\mathrm{K}$, Jacob Balde und die bayerische Historiographie unter Kurfürst Maximilian I. Ein Kommentar zur Traum-Ode (Silvae 7,15) und zur Interpretatio Somnii, Münchner Balde-Studien 5 (Munich: 2014) 70-94.

7 The work was reprinted in Ingolstadt in 1633, and again in Halle in 1708, this time with an introduction by the jurist and philosopher Nicolaus Hieronymus Gundling; this introduction was reprinted in Gundling's Observationum selectarum ad rem litterariam spectantium 
period ranging from the death of Charles $\mathrm{V}$ and the accession to the throne of Philip II to the arrival of the Count of Alba in the Low Countries after the Iconoclastic Fury (Beeldenstorm) of 1566 . He chose, therefore, a relatively short span of time, the critical years leading up to the Revolt itself. ${ }^{8}$ Before leaving the Low Countries he had been encouraged by Petrus Peckius, chancellor of the county of Brabant, to write a larger history of the Low Countries, ${ }^{9}$ which however never materialized. In his Historia Belgica, then, Burgundius looked back upon the origins of the Revolt, about 60 years after the events he chronicled, at a time when, after the end of the Twelve Years' Truce, military violence had flared up again, the Revolt had become entangled in larger international conflicts, not least the Thirty Years' War, and the hope of reuniting the Low Countries had all but vanished.

Burgundius dedicated his Historia Belgica to Duke Maximilian, in a gesture of gratitude for his recent appointment in Ingolstadt: 'Agnosco enim quo me favore exceperis, cum e Belgio evocatum celeberrimae Tuae Academiae Ingolstadiensi adscripsisti' ('For I acknowledge the goodwill with which you received me, when you called me forth from the Low Countries and appointed me in your most famous university at Ingolstadt'). ${ }^{10}$ In this dedication he ingeniously connects the obligatory praise of his dedicatee with an explanation of both his historiographical approach and the moral and political benefit to be drawn from it:

Videbis virtutis vitiorumque certamen. Videbis perfidiam cum fide luctantem sectasque nostrorum temporum in religionem attollentes supercilium, breviter, quidquid malorum prorupit in publicam perniciem ex aemulatione et invidia Magnatum Principi suo non sat obedientium [...]. Pulchrum tibi erit alienae gentis calamitates percurrere, ut subditorum tuorum felicitatem agnoscas, quos pestilentissimum hoc sydus nunquam

tomus II, editio secunda (Halle, Renger: 1737) 205-228. Burgundius's Historica Bavarica similarly enjoyed renewed attention at the turn of the 18th century, as a reprint was issued in Helmstedt in 1705, with an introduction by the theologian Justus Christoph Böhmer.

8 This period corresponds roughly with the phase for which Robert Fruin coined the term 'voorspel' ('prelude') of the Revolt. The same time span is covered in De initiis tumultuum Belgicorum (1587), composed by Florentius vander Haer, who is the most important Latin author on the Catholic side to compose a historical work on the Revolt before Burgundius. See Britz, "Bourgogne" 854, and Vermaseren B.A., De katholieke Nederlandsche geschiedschrijving in de XVIe en XVIIe eeuw over den Opstand (Maastricht: 1941) 267. Peckius had earlier tried to motivate Erycius Puteanus to write such a work; see Vermaseren, ibidem 209.

10 Burgundius, Historia Belgica (fol. 3r). All quotations are from the 1708 edition of the Historia Belgica. 
afflavit, in mediis tamen collidentium inter se religionum fluctibus deprehensos.

You will see a battle between virtue and vices. You will see treachery struggling with loyalty and the factions of our times looking down on religion with disdain, in sum, whatever evil burst forth and caused the ruin of the state, because of the rivalry and hatred of the high nobility, who did not sufficiently obey their sovereign ruler [...]. It will be pleasant for you to observe the calamities of a foreign nation, so that you will recognize the happiness of your own subjects, who were never affected by this most destructive constellation, even although they were caught in the midst of the billows of clashing religions. ${ }^{11}$

Burgundius' account, in other words, is a story of disruption and chaos, brought about by unruly and overambitious noblemen, a stark counterexample to the harmonious reign in Bavaria, for which Duke Maximilian is implicitly credited. The political and religious turmoil that led to the disintegration of the Low Countries is presented as a negative showcase that underlines by contrast the unfailing governing skills of Duke Maximilian in the exacting climate of the Thirty Years' War. In addition, Burgundius associates himself firmly with his new patron through his unequivocally pro-Spanish and pro-Catholic stance.

At the same time, Burgundius endows his report of the prelude to the Revolt with an exemplary quality beyond its historical contingency by defining its essence as a 'battle between virtue and vices', a kind of "psychomachia" between good and evil. In his preface, he elaborates this motif and highlights the everchanging balance of power between the people, a privileged ruling class, and an autocratic ruler, provoking a continuous sequence of peace and war. The Dutch Revolt, too, is a manifestation of the same play, staged over and over again on the 'scena rerum humanarum' ('the stage of human affairs'), ${ }^{12}$ which writers record for the purpose of moral instruction by means of 'exempla. ${ }^{13}$ In this way, Burgundius immediately emphasizes the fundamental relevance of his work for an international cultured audience: the Dutch Revolt illustrates basic characteristics of the course of world history, and therefore his Historia

\footnotetext{
11 Burgundius, Historia Belgica (fol. 2r-v).

12 Burgundius, Historia Belgica 2: 'Nam qui haec leget, facile discet scenam rerum humanarum' ('For he who will read this work, will easily become acquainted with the stage of human affairs').

13 Burgundius, Historia Belgica 2: 'Quippe nemo rectius quam exemplis instruitur' ('For no one is taught more properly than by means of examples').
} 
Belgica is essentially an autopsy of human nature; the facts and events reported in it are typical instances of human experience tout court.

Burgundius' particular approach can be grasped even more clearly by comparing the dedication and the preface of his work with the introduction of the sole historiographical treatise, prior to Burgundius, in which exactly the same period was treated, Florentius vander Haer's De initiis tumultuum Belgicorum (Douai, Jean Bogard: 1587). ${ }^{14}$ Vander Haer dedicated his work to Alessandro Farnese, then Governor of the Southern Low Countries, and praised extensively his military prowess; his work itself reads to a large extent as a tribute to Farnese's mother, Margaret of Parma ( $\dagger 1586)$, Governor of the Southern Low Countries during the so-called 'prelude' to the Revolt. In the course of the treatise Vander Haer focussed ever more strongly on the political leadership of Margaret of Parma, who successfully opposed heresy and restored royal authority, thus paving the way for her son's later accomplishments. ${ }^{15}$

Not only did vander Haer's choice of dedicatee provoke a different assessment of some of the leading characters of his narrative, ${ }^{16}$ but also Burgundius' analysis of the events operates on a different level. Vander Haer, and others with him, had identified three fundamental causes of the Revolt: the personal enmity between William of Orange and Antoine Perrenot de Granvelle, ${ }^{17}$ the introduction of new bishoprics and the spread of Calvinism in the Low Countries. ${ }^{18}$ Burgundius, instead, searched for deeper causes in the psyche of the main actors:

Mehercule vero, nihil ego populari invidiae non attribuo. Novis tamen episcopatibus et Inquisitioni et edictis, quibus tum maxime irascebantur, cuncta non imputo. Altiores causae stimulabant Proceres in facinus. Furor et ambitus caecos obsederat. De cetero Inquisitionis edictorumque larvas palam assumpserant, ut sub honesto titulo litarent invidiae suae et publicae utilitatis speciem aemulationi praeferrent.

14 See Haitsma Mulier E.O.G. - van der Lem A., "Haer, Florentius (Floris) vander" (2012), at http://www.dutchrevolt.leiden.edu/dutch/geschiedschrijvers/Pages/haer.aspx (retrieved 8th August 2017).

15 Vermaseren, De katholieke Nederlandsche geschiedschrijving 145-148.

16 Margaret of Parma, e.g., appears far less decisive and efficient in Burgundius's Historia Belgica than in vander Haer's De initiis tumultuum Belgicorum.

17 For a brief biographical profile of Granvelle see van der Lem A., "Antoine Perrenot, kardinaal Granvelle" (2012), at http://www.dutchrevolt.leiden.edu/dutch/personen/G/Pages/ granvelle_antoine.aspx (retrieved 8th August 2017).

18 Vermaseren, De katholieke Nederlandsche geschiedschrijving 147. 
True enough, I attribute everything to the resentment of the people. I do not impute the whole blame, however, to the new bishoprics, the inquisition, and the edicts, which infuriated people at the time most strongly. Deeper causes incited the nobility to their crime; rage and greedy ambition had made them blind. Also, they had patently taken the inquisition and the edicts as empty cloaks ('ghosts') to satisfy their own grudge under a respectable pretext and to cover their contention in a guise of public benefit. ${ }^{19}$

In other words, Burgundius aimed to uncover the reality underneath the appearances, to unmask the real motives and strategies of the protagonists of his historia.

\section{Tacitus and Tacitism in the Historia Belgica}

Any 17 th-century reader of the Historia Belgica would associate a reference to 'altiores causae' immediately with the historiography of Tacitus. Especially under the impulse of Justus Lipsius, but even before, ${ }^{20}$ early modern editors and commentators of Tacitus emphasized that Tacitus provided unique insights into the 'deeper causes' of political action and communication in an autocratic regime. Since Justus Lipsius and others perceived their own times to be strikingly similar to the era described by Tacitus, Tacitus became all the more relevant as an instructor of the political trade, ${ }^{21}$ especially for the new functional elites in government, jurisprudence, and administration the social class to which Burgundius himself also belonged. We may assume,

\footnotetext{
19 Burgundius, Historia Belgica 88-89.

20 A relevant passage from the preface of Puteolanus' edition is quoted by Etter E.-L., Tacitus in der Geistesgeschichte des 16. und 17. Jahrhunderts, Basler Beiträge zur Geschichtswissenschaft 103 (Basel - Stuttgart: 1966) 173.

21 This notion of similitudo temporum was made famous by Justus Lipsius in the dedication of his edition of Tacitus's Annales (1574) and the dedication of his commentary on that work (1581). In the modern edition of Lipsius' letters, the Iusti Lipsi Epistulae (Brussels, from 1978 onwards), the texts can be found in ILE I, 7407 oo M, at 38-39 and ILE I, 81 oo oo $\mathrm{H}$, at $25^{-26}$. The idea had been mentioned before by Machiavelli, and the term similitudo temporum appears also in the famous oration (1580) of Marcus Antonius Muretus, in which he defends himself against those who had criticized his lectures on Tacitus at the Sapienza; see Etter, Tacitus 16.
} 
therefore, that these counsellors, jurists, and administrators were the audience Burgundius intended for his work. ${ }^{22}$

Already six years before the publication of the Historia Belgica, Valerius Andreas hinted in his note on Burgundius in his Bibliotheca Belgica (Louvain, Henricus Hastenius: 1623) at the Tacitean orientation Burgundius was going to adopt:

Meditatur Historiam Belgicam, in qua praeter obsidiones, pugnas, pacta eventusque tractat artes, fraudes, rationem causasque eorundem, quae vel potissimae sunt historiae partes et leges.

He is planning a History of the Low Countries, in which he discusses not only sieges, battles, pacts, and events, but also tactics, deceit, their reason and causes, which are by all means the principal parts and laws of history. ${ }^{23}$

This characterization contains a reminiscence of Tacitus, Historiae I, 4, 1 ('ut non modo casus eventusque rerum, qui plerumque fortuiti sunt, sed ratio etiam causaeque noscantur'). ${ }^{24}$ Burgundius himself picks up one other of Tacitus' programmatic statements, when he declares that he will write 'sine amore, sine

22 On the various facets and implications of Tacitism in these milieus see especially the fundamental study of Kühlmann W., Gelehrtenrepublik und Fürstenstaat. Entwicklung und Kritik des deutschen Späthumanismus in der Literatur des Barockzeitalters (Tübingen: 1982), and from his later studies above all "Geschichte als Gegenwart. Formen der politischen Reflexion im deutschen Tacitismus des 17. Jahrhunderts", in Neumeister S. - Wiedemann C. (eds.), Res Publica Litteraria. Die Institutionen der Gelehrsamkeit in der Frühen Neuzeit, Wolfenbütteler Arbeiten zur Barockforschung 14 (Wiesbaden: 1987), vol. I, 325-348.

23 Quoted by Vermaseren, De katholieke Nederlandsche geschiedschrijving 267, with n. 545 . In his bio-bibliographical survey of Latin literature in the Low Countries Valerius Andreas quite often mentions writings that are "being planned"; in those cases 'meditatur' is his standard term. I have not been able to ascertain whether he speaks about Burgundius's Historia Belgica from first- or second-hand knowledge. Burgundius may have shown and discussed (parts of) his work among friends and acquaintances before its publication. In any case, he worked extensively on his Historia Belgica before his departure to Ingolstadt; see, e.g., the letter, in which Puteanus tried to repair the relationship with his former student (Erycii Puteani Epistolarum apparatus novus et miscellaneus [Amsterdam: Jodocus Janssonius: 1646], cent. IV, epist. 40): 'Huius tibi iam specimen elaboratum scio' ('I know you have already fully worked out an example [of historiographical writing]'; ibidem 3637 , at 36$)$.

24 The allusion is quite elegant: the key terms 'eventus', 'ratio', and 'causae' are taken over directly from Tacitus, whereas 'quae vel potissimae sunt historiae partes et leges' is a Kontrastimitation of 'qui plerumque fortuiti sunt'. 
odio partium, quibus hactenus vitiis maxime laboratum est' ('without love or hatred towards the parties involved, the vices which until now have tormented people most severely'), ${ }^{25}$ thus reiterating Tacitus' profession of impartiality at Historiae I, 1, 3 ('sed incorruptam fidem professis neque amore quisquam et sine odio dicendus est'). ${ }^{26}$

Burgundius, then, firmly espoused the widespread revalorization of Tacitus, which in the 2oth century came to be labelled as 'Tacitism. ${ }^{27}$ Burgundius most likely inherited his appreciation of Tacitus from his professor at Louvain, Erycius Puteanus, whose views on Tacitus largely concurred with those of his predecessor, Justus Lipsius, the most important initiator of the entire Tacitean current. ${ }^{28}$ The modern term "Tacitism", however, is an umbrella term for various modes and strands of the reception of Tacitus with respect to both content and style. The present state of scholarship concerning these different facets of the Tacitean tradition is quite uneven. Whereas there is a long tradition of scholarship, e.g., on the impact of Tacitus on 16th- and 17th-century political thought or on the reception of Tacitus' Germania in early German humanism, there hardly exist any extensive studies - surprisingly so - on the scope and nature of the reception of Tacitus in early modern historiography. ${ }^{29}$

25 Burgundius, Historia Belgica 4.

26 Burgundius applies the statement more explicitly to himself than Tacitus, who relates the observation in a general fashion to the "professi incorruptam fidem" (those who profess impeccable sincerity - the context of the passage, of course, invites the reader to add 'like I do').

27 The term appears to have been coined by Giuseppe Toffanin; see his Machiavelli e il "tacitismo". La "politica storica" al tempo della controriforma (Padova: 1921). Good recent introductions (with the essential bibliography) to this broad and complex topic include Grafton A., "Tacitus and Tacitism", in Grafton A. - Most G.W. - Settis S. (eds.), The Classical Tradition (Cambridge, MA: 2010) 920-924, and Poel M. van der - Waszink J., "Tacitismus", in Historisches Wörterbuch der Rhetorik, vol. IX (2009) 409-419.

28 Puteanus offers a succinct appraisal of Tacitus in his declamation "In Tacitum affectus, brevi encomio expressus", included as "Oratio XXI" in his Suada Attica sive Orationum selectarum syntagma ([Leiden], Elzevier: 1623) 442-458. He delivered this oration, just as most of the other ones collected in his Suada Attica, in his Palaestra Bonae Mentis, the "academy" he founded within the venerable Collegium Trilingue at Leuven; during his student years Burgundius was a member of this community. Naturally, Tacitus is praised above all for the insights he offers into the inner workings of monarchical rule (the arcana imperii, in Tacitus's own words: Ann., 2, 36, 1), thus providing highly useful information to those who prepare themselves for a career in government and administration. Among the oratorical exercises performed at the Palaestra Bonae Mentis, one was devoted to the topic 'Historia Politicae officina est' ('history is the workshop of politics'); see Simar, Puteanus 131, n. 1.

This desideratum is pointed out by van der Poel - Waszink, "Tacitismus" 411. 
The rise of early modern "Tacitism" went hand in hand with a growing attention for the analysis of political reality from the viewpoint of the political actors, rather than the forms and functions of different structures of government. This shift from a theoretical to a pragmatic focus can be noticed both in works of political theory and in historiography. Even in the case of the most famous "Tacitist" historians, however, such as Famiano Strada and Hugo Grotius in Latin or Pieter Corneliszoon Hooft in Dutch, the nature and extent of their reception of Tacitus are not easy to pin down, and scholars have only recently begun to investigate this question in depth. ${ }^{30}$ Burgundius, too, who was a contemporary of these better known "Tacitist" historians, but published his Historia Belgica before they brought out their respective works, explicitly signals the Tacitean vein of his treatise and evidently considered Tacitus' Annales and Historiae a suitable reference framework for his own historical account. In what way and to what extent, then, did Burgundius recount and interpret the 'prelude' to the Revolt through the prism of Tacitus's Annales and Historiae? And in what sense is Burgundius' appropriation of Tacitus motivated by more than literary interests of imitatio and aemulatio, typical of Renaissance humanism in general? ${ }^{31}$

30 For recent attempts to grasp more accurately the characteristics of Tacitism, and particularly its interconnection between style and content, in Neo-Latin historiography see several studies of Jan Waszink, among which "Shifting Tacitisms. Style and Composition in Grotius's Annales", Grotiana 29 (2008) 85-132, "Your Tacitism or Mine? Modern and Early-Modern Conceptions of Tacitus and Tacitism", History of European Ideas 36, 4 (2010) 375-85, "Lipsius and Grotius: Tacitism", ibidem 39, 2 (2013) 151-168; Marc van der Poel, "Tacitean Elements in Grotius's Narrative of the Capture of Breda (1590) by Stadtholder Maurice, Count of Nassau (Historiae, Book 2)", Grotiana 30 (2009) 207-246, and Coen Maas, "Was Janus Dousa a Tacitist? Rhetorical and Conceptual Approaches to the Reception of Classical Historiography and its Political Significance", in Enenkel K.A.E. - Laureys M. Pieper C. (eds.), Discourses of Power. Ideology and Politics in Neo-Latin Literature, Noctes Neolatinae 17 (Hildesheim - Zurich - New York: 2012) 233-248.

31 On a fundamental level, the precepts of historiography, defined by Renaissance humanists, were entirely embedded in the requirements of the narratio in classical rhetoric. Any humanist historiographer, therefore, automatically thought or at least had to think about style - naturally always with the classical model authors in mind - in an effort to combine adherence to the truth and moral and rhetorical effectiveness; see my "The Theory and Practice of History in Neo-Latin Literature", in Ford Ph. $(\dagger)$ - Bloemendal J. - Fantazzi Ch. (eds.), Brill's Encyclopaedia of the Neo-Latin World (Leiden - Boston: 2014) 363-375, at $366-367$. For an emphatic defense and detailed illustration of the idea that classical historians need to be understood first and foremost as literary artists rather than recorders of events see the pioneering studies of Wiseman T.P., Clio's cosmetics. Three studies in GrecoRoman literature (Leicester: 1979) and Woodman A.J., Rhetoric in classical historiography. Four studies (London - Sydney: 1988). 

Belgica

Burgundius connects his own historiography with Tacitus in various ways. First, without explicitly associating contemporary political actors with Tacitean characters - as, e.g., Lipsius did, comparing the Duke of Alba to Tiberius ${ }^{32}$-, he draws to an important extent on Tacitus, and particularly in a pejorative sense, in his portrayals of some of the main actors in his Historia Belgica. Here is how he characterizes William of Orange, when he first speaks about William's defamation campaign against Granvelle:

Erat enim ingenio solers ${ }^{33}$ et demerendis hominibus ${ }^{34}$ aptus, ${ }^{35}$ splendore familiae, iuxta opibus potens, quamvis plerumque falsa et inania ${ }^{36}$ ingereret, tamen cum fide audiebatur. Quippe multis opinionem fecerat penetrasse se in arcana regis, ${ }^{37}$ cuius innocentiam modeste criminabatur; fluxam illi fidem, ${ }^{38}$ nec principe dignam; peregrinis consiliis imbutum et Granvellano obnoxium, in summo imperio non nisi imperium cogitare.

For he had a shrewd mind and was skilled in winning the esteem of men, he had power because of the splendour of his family and also thanks to his wealth. Although he poured out for the most part false and empty blabber, he was nonetheless listened to with confidence. In fact, to many he had sparked the rumour that he had provided himself access to the innermost secrets of the King, whose innocence he mildly complained about; his loyalty was fluctuating, unworthy of a ruler; he was infected with foreign counsels and mean-spirited towards Granvelle, and in the pinnacle of power he could not think anything but power. ${ }^{39}$

32 Justus Lipsius, Orationes octo Ienae potissimum habitae, e tenebris erutae et in gratiam studiosae iuventutis foras productae (Darmstadt, Balthasar Hofmann: 1607) 35. Lipsius delivered these orations in 1572 . Throughout the entire Tacitist movement, the emperor Tiberius, as portrayed in Tacitus's Annales, was always at the centre of the discussion.

33 After Tacitus, Historiae IV, 13, 2.

34 After Velleius Paterculus, Historiae II, 102, 1.

35 All three editions read 'apto', but the nominative is clearly required here. 'apto' seems to be influenced by the preceding ablative ('ingenio') and dative ('demerendis hominibus').

36 A common iunctura, but compare especially Tacitus, Annales III, 8, 2, and XVI, 8, 1.

37 After Tacitus, Annales II, 36, 1.

38 A common iunctura, but compare especially Sallust, Bellum Jugurthinum, 111, 2; Tacitus, Historiae II, 75, 1 and III, 48, 2.

39 Burgundius, Historia Belgica 21. The final observation, clearly modelled as an epigrammatic sententia to round off the entire passage, alludes to the characterization of the 
William's subversive mindset is particularly dangerous because of his perfect mastery of doublespeak, a crucial requirement of successful political communication in a court environment:

nihil temere loqui, egregie dissimulare, ${ }^{40}$ aliud lingua praeferre, aliud pectore claudere, ${ }^{41}$ tutissima quaeque metuere ${ }^{42}$ - magnae sane virtutes, quoties in virum bonum et civilia patientem inciderint.

To say nothing rashly, to feign superbly, to express one thing in speech, but to hide something else in your heart, to dread even all the most secure things - great virtues for sure, whenever they occur in a good man, who submits to civility. ${ }^{43}$

Second, in his analysis of the political situation and course of events, Burgundius picks up motifs from Tacitus. Throughout the first book of his Historia Belgica he evokes the personal enmity between William of Orange and Granvelle, which they pursued to the detriment of public interest and welfare. At the beginning of Book 2, their 'privata odia' are cited as the main topic of Book 1: 'Hactenus quidem adhuc privata odia videri poterant' ('Up to that time, in fact, one could still see only private enmities'). ${ }^{44}$ This contrast between private vice and public benefit occurs of course in several ancient authors, but is a conspicuous leitmotiv in Tacitus' account of the Pisonian conspiracy (Annales XV, 73, 3: 'ne publicis malis abuti ad occasionem privati odii videretur'). The phrase 'privata odia' further recalls Tacitus' comment on Octavian's pursuance of the murderers of Julius Caesar: 'quamquam fas sit

tyrant in the dedication of Justus Lipsius' Politica: 'Mali improbique illi, qui in imperio non nisi imperium cogitant' ('Bad and evil are those, who, being in power, think of nothing but power'); see Justus Lipsius, Politica. Six books of politics or political instruction, ed. and trans. J. Waszink, Bibliotheca Latinitatis novae 5 (Assen: 2004) 228.

40 A key notion in the theory and practice of political communication in the 16th and 17 th centuries. For a wide-ranging exploration of the concept of dissimulatio see Geitner U., Die Sprache der Verstellung. Studien zum rhetorischen und anthropologischen Wissen im 17. und 18. Jahrhundert, Communicatio 1 (Tübingen: 1992), and Snyder J.R., Dissimulation and the culture of secrecy in early modern Europe (Berkeley: 2009). In connection with Tiberius see especially Tacitus, Annales IV, 71, 3 and VI, 50, 1.

41 After Sallust, De coniuratione Catilinae 10, 5.

42 A common iunctura, perhaps best known from Virgil, Aeneis IV, 298.

43 Burgundius, Historia Belgica 27. Taken at face value, the whole passage from which this quotation is taken, could indeed be read as praise, but the restrictive final point turns it in malam partem - a superb example of literary simulatio. 
privata odia publicis utilitatibus remittere' (Annales I, 10, 3). Burgundius uses this pair of opposites to measure the degree of moral corruption in the state: when William of Orange first started rallying for supporters, Burgundius notes: 'Neque enim usque adeo corrupti mores erant, plerisque adhuc privatas simultates sic exercentibus, ut salutis publicae curam non deponerent'45 ('For their character was not corrupted all the way through; most of them fought out their quarrels, which until then still remained private, in such a manner, that they would not abandon the care for the safety of the state'). Tacitus' pessimistic references to the difficult times he is writing about - marked as they were by a general moral decay (e.g., Annales III, 65, 2) -, were also echoed by Burgundius; he repeatedly calls attention to the 'malignitas temporum' 46 and at one point refrains from blaming the Count of Egmont personally for what he sees as a general moral decline: 'At perperam uni illi imputaverim culpam, quae temporum fuit' ('But I would be wrong to attribute to him alone a fault, which was typical of those times' $).{ }^{47}$ Here it is obvious that Burgundius intends to evoke a sense of similitudo temporum.

Third, like Tacitus, Burgundius focuses on the psychology of the main characters. He observes and interprets the events of the history he records through the thoughts, feelings, and moods of the personalities who shaped that history. And again like Tacitus, he conveys these inner motivations, compulsions or longings that inspire and steer their actions in large part through direct and indirect speech. We witness, for instance, how William of Orange and Viglius of Aytta, who was along with Granvelle one of the most influential counsellors of the Governor Margaret of Parma ${ }^{48}$ discuss the question how to react to the sharper measures, ordered by King Philip II for the Inquisition in the Low Countries: both William of Orange and Viglius expound their views, cast by Burgundius in a mixture of direct and indirect speech, and Margaret, wavering back and forth for some time, finally gives in to William's plea for a strict endorsement of the King's policy, even although she senses the violent reactions it may trigger; in reality, of course, provoking this policy to backfire was William's plan all along, and consequently, he was very pleased with the

\section{Burgundius, Historia Belgica 27.}

46 The term occurs at Historia Belgica 60 and 145. When Burgundius addresses the question who was responsible for sparking the Iconoclastic Fury, he declares (Historia Belgica 117): 'Ego vero ut non unum aliquem populum, ita iniuriam temporum accusare non desino, mutationem rerum portendentium' ('I, for one, do not cease to accuse not one single group of people, but rather the lawless violence of the times, portending a revolution').

47 Burgundius, Historia Belgica 167.

48 See "Aytta van Zwichem, Wigle van (Viglius)" (2012), at http://www.dutchrevolt.leiden .edu/dutch/personen/V/Pages/viglius.aspx (retrieved 8th August 2017). 
outcome of the discussion: 'Laetus ergo Auriacus atque renidens ${ }^{49}$ proxime sibi assidenti susurravit in aurem visuros se propediem ingentem tragoediam, 50 ('And then the Count of Orange, cheerful and beaming, whispered in the ear of the person sitting next to him that they would witness before long an immense tragedy').

In a similar fashion Burgundius also presents the deliberations that went on at the royal court in Madrid. At a certain point, the question was debated how and with what show of force the King himself could restore order, if he were to come to the Low Countries himself. Burgundius reports two orations in direct speech, one by the Count of Feria, who pleaded for a more cautious and conciliatory attitude, and another by the Duke of Alba, who defended a hard line to quench the revolt. Both interventions, contrasted with each other in the best rhetorical manner like a debate in utramque partem with arguments pro and contra, read like a compact manual of statecraft. Alba's view, Burgundius adds, made the more significant impact: 'Haec oratio, simul et dicentis auctoritas inveterataque prudentiae ${ }^{51}$ fama, magnam procerum partem permovit'52 ('This speech, as well as the authority of the speaker and his long-standing reputation of political wisdom, deeply moved a large part of the noblemen'). One is reminded here of the senatorial debates vividly related by Tacitus, especially in his Historiae. At times Tacitus, too, pits two opponents against each other and articulates their confrontation - obviously to maximum rhetorical effect - in two contrasting speeches, such as the 'acre iurgium' ('fierce altercation') fought out between the rival senators Helvidius Priscus and Eprius Marcellus on the question whether envoys to be sent to the new emperor Vespasian should be designated by the magistrates or picked out by lot (Tacitus, Historiae IV, 7-8). Being a trained lawyer, Burgundius can be expected to have a special interest in this kind of political rhetoric.

Through the speeches of his main characters, as well as through letters and other documents that are quoted verbatim, Burgundius also evokes the main points of contention in the contemporary political and religious controversy in the Low Countries: the new bishoprics and the position of Granvelle, the organization of government, especially the role of the (higher) nobility and its relationship to the central rule of the Spanish monarchy, and the question of religious toleration vis-à-vis safeguarding orthodoxy. In an address to the

49 After Tacitus, Annales IV, 6o, 2 about Tiberius: 'falsum renidens vultu'.

$50 \quad$ Burgundius, Historia Belgica 51.

$5^{1} \quad$ Another key concept of early modern political theory and practice.

$5^{2}$ Burgundius, Historia Belgica 158. Burgundius uses this occasion to defend Alba against accusations of deceit. 
reader ('Ad lectorem') ${ }^{53}$ Burgundius states that he has been able to rely on 'fidelissima manuscripta' ('most trustworthy documents'), namely private notes taken by Viglius of Aytta at the councils in the Low Countries and reports of Charles of Tisnacq concerning the Spanish councils, ${ }^{54}$ as well as the correspondence exchanged between Philip II and Margaret of Parma. Since these papers of Viglius and Tisnacq have not been preserved, it is difficult to judge to what extent they actually influenced or shaped Burgundius' account. Of the letters and missives sent back and forth between the Spanish king and his half-sister large parts are still available in numerous copies, but a comparison with corresponding sections in Burgundius' Historia would nonetheless be fraught with difficulties and uncertainties, because it is impossible to ascertain what kind of version of these documents Burgundius would have read. ${ }^{55}$ Most if not all of this material, in addition, was written in one of the vernacular languages used in the state affairs of the Habsburg empire; Burgundius' renderings presuppose, therefore, in any case a translation into Latin. ${ }^{56}$ Most often Burgundius seems to have rephrased and shortened the documents he used; at times he says so with a formula such as 'in hanc sententiam', 'in hanc summam', 'in haec verba' or 'in hunc modum. ${ }^{57}$ In the case of some crucial texts he is a little more explicit about how he handled his source material. When he writes out a Latin version of the Compromise of Nobles (the 'formula coniurationis' in his own terms!) from December 1565, he remarks: 'Ipsa fere retuli verba, sicut erant

53 Burgundius, Historia Belgica, fol. 3v.

54 Charles of Tisnacq was another important counsellor of Philip II. During most of the 1560 s he resided in Spain as Keeper of the Seals of Philip II. See Baelde M., "Tisnacq sr., Charles de" (2012), at http://www.dutchrevolt.leiden.edu/dutch/personen/T/Pages/ tisnacq.aspx (retrieved 8th August 2017).

55 Compare the case of Tacitus, Annales, 11, 24, where Tacitus reports a speech of the emperor Claudius, held in the Roman senate. By a stroke of luck, the original speech is partly preserved on a bronze tablet, discovered in 1528 in Lyon (CIL XIII, 1668). It is obviously very interesting to compare both versions (for a detailed comparative analysis see von Albrecht M., Meister römischer Prosa von Cato bis Apuleius, 2nd edition [Heidelberg: 1983] 164-189), but we cannot know in what form exactly Tacitus read Claudius' speech. Likewise, when Tacitus mentions that a particular speech of Tiberius has been preserved (Annales II, 63, 3: 'extat oratio'), it remains unclear in what kind of version Tacitus would have been able to consult this text.

$5^{6}$ I am grateful to Hans Cools for enlightening me on the complexities of the correspondence between Philip II and his administrators in the Low Countries, in particular the languages used in the different categories of letters and the various translation processes that could occur between dictation and redaction of the letters at the courts in Brussels and Madrid.

Burgundius, Historia Belgica 67, 93, 103, and 110 respectively. 
incompta atque acerba, quantum Latino sermone assequi licuit'58 ('I rendered more or less the very words [of the original text], in all their roughness and bitterness, as much as I was permitted to match them in the Latin language'). Occasionally, he explains why he takes pains to quote a source in full, such as, e.g., one of Philip's notorious letters from the Segovia woods, where he feels a need to defend the King's reputation: 'Hanc utique epistolam in longum transcripsi, non ut moli voluminis aut copiae consulerem [...], sed ut boni regis famam calumniis exonerem'.59 ('I transcribed at least this letter in full, not to make sure that my work be ponderous or luxuriant, but to free the reputation of the good king from false accusations').

Time and again, Burgundius exploits these speeches and letters to evince the basic tenets of contemporary political thought, particularly concerning the role of religion in politics and government - a topic that looms large over the entire Historia Belgica. In an address to the Knights of the Order of the Golden Fleece, held on 30 November, the feast day of the Order's patron, Saint Andrew, of the year 1565 , Viglius, the Order's Chancellor, states his belief in the fundamental unity of church and state as an essential requirement for any harmonious society: 'Basim et fundamentum rei publicae religionem esse; sine illa humanarum rerum regimen stare non posse'.60 ('Religion is the basis and foundation of the state; without it no governance of human affairs can stand firm'). And with regard to religion, both nobility and kings have their set place and task:

Tutelam eius omnibus incumbere, ac imprimis principibus viris, ad prodendum in vulgus exemplum. Ceteros mortales regibus subici, reges autem Ecclesiae, nec eam esse aliam quam Romanam, hoc est Christi Ecclesiam, quae a temporibus apostolorum continua serie ad nos descendens Beatum Andream huic Ordini patronum dederit.

Safeguarding it is everyone's duty, and above all that of the leading ranks, to set an example for the common folk. Kings have all other people as subjects, but are subjected themselves to the Church, and this can only be the Roman Church, that is the Church of Christ, which came down to

$5^{8}$ Burgundius, Historia Belgica 66 . For the text of this covenant, signed mainly by members of the lower nobility, see "Het verbond der edelen 1566" (2012), at http://www.dutchrevolt .leiden.edu/dutch/bronnen/Pages/1566ooooned.aspx (retrieved 8th August 2017).

59 Burgundius, Historia Belgica 115.

6o Burgundius, Historia Belgica 61. 
us from apostolic times in an unbroken lineage and gave us Saint Andrew as the patron of this Order. ${ }^{61}$

First and foremost, Viglius wanted to remind the Knights of their obligation to defend - under the leadership of the Order's Grand Master, Philip II - the Church against all her enemies. Viglius', and - we assume - also Burgundius' view, compressed here in the most lapidary form, simply reflects a key notion of Counter-Reformation political theory. ${ }^{62}$ Viglius' statement, however, also serves to underline the interconnection between the two fundamental aberrations of the nobility that to Burgundius' mind characterized the Revolt: they had forsaken both their proper place and task in society.

Burgundius's recourse to Tacitus, then, in moulding the representation of a crucial episode from recent national history cannot be adequately described as one of the political-ideological variants of 'Tacitism', as defined by Giuseppe Toffanin and Peter Burke. ${ }^{63}$ First of all, we should not rule out or ignore Burgundius's literary aspirations. For Burgundius, just as for any humanist historian, historiography was an 'opus oratorium maxime' (Cicero, De legibus I, 5). Any historiographical work, therefore, necessarily required a studied dispositio and an elaborate ornatus. The claim to veritas (the 'prima lex historiae', according to Cicero, De oratore II, 62), moreover, was not a claim to objective truth, but rather to an accurate and persuasive representation of reality,

61 Burgundius, Historia Belgica 61.

62 For a discussion of Viglius' speech see Postma F., "Prefigurations of the future? The views on the boundaries of Church and State of William of Orange and Viglius van Aytta (1565-1566)", in McDonald A.A. - Huussen A.H. (eds.), Scholarly Environments. Centres of Learning and Institutional Contexts, 1560-196o (Louvain - Paris - Dudley, MA: 2004) 15-32, at $19-20$.

63 The inadequacy of the categorizations of Tacitism, proposed by Toffanin and Burke, has been justly criticized by Karl Enenkel and Olga E. Novikova, "Nieuwe wereld - nieuwe klassieken. De ontdekking van Tacitus in de 16de en vroege 17 de eeuw", in Enenkel K.A.E. van Heck P. (eds.), De mensen van vroeger, de hoven van weleer. Over de receptie van de klassieken in de Europese literatuur (Voorthuizen: 2001) 13-53, at 45-47, and by Coen Maas, "Was Janus Dousa a Tacitist? Rhetorical and conceptual approaches to the reception of classical historiography and its political significance", in Enenkel K.A.E. - Laureys M. Pieper C.H. (eds.), Discourses of power. Ideology and politics in Neo-Latin literature, Noctes Neolatinae 17 (Hildesheim: 2012) 233-248, at 235-239. 
such as an orator was trained to deliver. ${ }^{64}$ Burgundius adopts a distinctive style, which is certainly not purely Tacitean, but by all means conspicuously non-Ciceronian. ${ }^{65}$ It seems that Burgundius tries to recreate above all the two markedly non-Ciceronian stylistic qualities that Tacitus shared with Sallust, namely (1) brevitas, brevity, but also implying narrative speed and vividness, ${ }^{66}$ not only conciseness of expression (a reaction against Cicero's copia verborum) and (2) inconcinnitas, asymmetry, avoidance of balanced phrases (a reaction against Cicero's concinnitas). In addition, Burgundius imitates another literary trait common to both Tacitus and Sallust, namely their fondness for sententiae, aphoristic statements, often used to round off a particular section.

Just as Tacitus himself drew more than once directly on Sallust in descriptions of both scenes and characters, Burgundius seems to want to link these two models authors in some of his literary reminiscences and refer back to Sallust through Tacitus. When Burgundius highlights William of Orange's outstanding skill at 'dissimulatio', 67 he obviously thinks of the concepts of simulatio and dissimulatio, as Tacitus illustrates them in his portrayal of Tiberius, but he also harks back to Sallust's character sketch of Catiline: 'cuius rei lubet simulator ac dissimulator' (Catilinae coniuratio 5, 4). Sometimes, however, the literary context is wider still: the characterization 'fluxam illi fidem', e.g., in another passage quoted above occurs in Tacitus (Historiae II, 75, 1), where it is applied to Roman soldiers in civil war, but Burgundius probably knew that Tacitus consciously ${ }^{68}$ uses here an expression that earlier authors had reserved for non-Romans, e.g. Sallust for Mauretanians (Bellum Jugurthinum 111, 2). With regard to William of Orange, therefore, Burgundius intends to suggest that his attitude and behaviour make him an undesirable dissolute outcast, whose proper place is not in the inner circle of the Spanish government, but among barbarians. And to corroborate this suggestion, Burgundius includes one further strategically chosen reminiscence: 'ingenio sollers' alludes to the Batavian ringleader Gaius Julius Civilis, of whom Tacitus has said: 'ultra quam barbaris solitum ingenio sollers' (Historiae IV, 13, 2).

It is clear, then, that Burgundius's stylistic practice does not merely serve the purpose of literary embellishment; it is designed to guide the reader to the

64 See especially Heldmann K., Sine ira et studio. Das Subjektivitätsprinzip der römischen Geschichtsschreibung, Zetemata 139 (Munich: 2011) 21-75.

65 Already Puteanus, Burgundius' teacher at the Palaestra bonae mentis in Louvain, had moved away from the markedly Tacitean style of his teacher and predecessor, Justus Lipsius.

66 Quintilian highlights Sallust's 'velocitas' (Institutio oratoria x, 1, 102).

67 See above p. 408.

68 Compare Historiae III, 48, 2: 'fluxa, ut est barbaris, fide'! 
author's interpretation of the events he narrates. It is for this interpretive guidance of the reader, rather than for the sake of a particular political ideology, that Tacitus's historiography is brought to bear; Toffanin's and Burke's understanding of Tacitism as a current of political thought, inspired by Tacitus' analysis of the early principate, therefore does not adequately cover Burgundius' use of Tacitus. The principal ideological question that transpires in the Historia Belgica pertains to the mutual relationship between religion and government, since the Dutch Revolt laid bare the dilemma of monarchical authority and how unity of religion helps consolidate it, on the one hand, and religious diversity and the right of opposition - the most extreme form of which would be civil war and tyrannicide - on the other, as Burgundius points out at the start of his work:

Proinde operae pretium duxi aggredi bellum, quo nullum umquam diuturnius aut acerbius Belgium habuit, tum conflictu totius orbis Christiani, cum atrocitate proeliorum et nutatione victoriae, exercitibus hinc pro religione et imperio, illinc pro vindicanda libertate non minore animo concurrentibus.

I have therefore considered it worthwhile to address the longest and fiercest war the Low Countries ever saw, both because the conflict concerned the entire Christian world and because its battles were hideous and victory swayed back and forth, with armies engaging in combat on one side for the sake of religion and the empire, on the other to claim liberty with no lesser zeal. ${ }^{69}$

For this question Tacitus was only partially relevant: Tacitus talked about civil discord and strife, about political intrigues and how to deal with them, about the inner secrets of imperial rule, but he had hardly anything to say about religion, apart from a few inconclusive remarks about a strange sect, called the Christians. Tacitus, moreover, could be convincingly exploited by both supporters and opponents of monarchy. Hugo Grotius in his Annales et Historiae de rebus Belgicis (Amsterdam, Blaeu: 1658$)^{70}$ chose a Tacitean perspective as

69 Burgundius, Historia Belgica 2. The beginning of this sentence evokes at once three famous openings of Roman historiographical works: Sallust's Bellum Jugurthinum (5, 1: 'Bellum scripturus sum'), Livy's Ab urbe condita (PR., 1: 'Facturusne operae pretium sim'), and Tacitus' Historiae (I, 2, 1: 'Opus aggredior').

70 The genesis of the Annales et Historiae goes back to 1601, when Grotius received a commission from the States of Holland to write this work, but in the end it was published only posthumously. 
well, but advanced a very different analysis of the Revolt. Burgundius may have loved freedom, but he had no sympathy for freedom-loving rebels.

Burgundius's ideological agenda, therefore, is not set by the model of Tacitus, but by contemporary political thought. ${ }^{71}$ Essentially, he espoused the traditional Catholic viewpoint: the Revolt was caused first and foremost by the higher nobility who had succumbed to an excessive hunger for power and wealth and forsaken its proper place and task in society, and most notably its obligations towards the King and the Catholic faith; William of Orange was but the most conspicuous exponent of that more general disorder. In Burgundius's Historia Belgica the reception of Tacitus seems to be grafted onto this contemporary political and ideological debate. In this way, Burgundius is able to devise a distinctive political rhetoric, in which form and content effectively reinforce each other. This rhetoric is already at work in Valerius Andreas' announcement of the Historia Belgica in his Bibliotheca Belgica (Louvain, Henricus Hastenius: 1623), ${ }^{72}$ for when Valerius Andreas characterizes the work by evoking a phrase from the prologue of Tacitus's Histories, he not only intimates that Burgundius will draw on Tacitus in his Historia Belgica, he also adds implicit emphasis to Burgundius's point that the Revolt is a story of fraud and deceit. Tacitus, in the passage just before the phrase Valerius Andreas directly refers to, had announced the subject matter of his work in similarly glum terms: 'Opus aggredior opimum casibus, atrox proeliis, discors seditionibus, ipsa etiam pace saevum'. (Tacitus, Historiae I, 2, 1: I am taking on the history of a period abounding in disasters, grim with battles, torn by insurrections, savage even in peace) - a passage Burgundius himself, too, had in mind when he wrote his preface. ${ }^{73}$ The underlying message is obvious enough: already in 1623 it was clear to Valerius Andreas that Burgundius was going to deny the Revolt any legitimacy whatsoever.

To conclude, rhetoric connects the literary and political dimensions of Renaissance humanism and the Neo-Latin literature it inspired. Ever since Petrarch and Salutati put their humanistic interests and literary expertise to use for political purposes, Renaissance humanists never stopped devising new modes of political discourse, characterized in form and content by humanistic values. It is in this context, I believe, the rise and development of humanist political rhetoric, that Burgundius's Historia Belgica needs to be interpreted above all. In Burgundius, I submit, we encounter Tacitism not as a political

71 Coen Maas, “Was Janus Dousa a Tacitist?" 238-239, reached the same conclusion with respect to Janus Dousa's Bataviae Hollandiaeque annales.

72 See above p. 404.

73 See above n. 69 . 
ideology, but as a pattern of political communication, informed by the humanist rhetoric of imitation and designed by Burgundius as a literary instrument for an adequate representation of the recent past of his homeland.

\section{Bibliography}

\section{Sources}

Burgundius Nicolaus, Historia Belgica ab anno MDLVIII (Ingolstadt, Wilhelm Eder Johann Bayr: 1629; reprinted ibidem: 1633); reprinted with an ample introduction by Nicolaus Hieronymus Gundling (Halle/Saale, Renger: 1708).

\section{Secondary Literature}

Enenkel K.A.E. - Novikova O.E., "Nieuwe wereld - nieuwe klassieken. De ontdekking van Tacitus in de 16de en vroege 17 de eeuw", in Enenkel K.A.E. - Heck P. van (eds.), De mensen van vroeger, de hoven van weleer. Over de receptie van de klassieken in de Europese literatuur (Voorthuizen: 2001) 13-53.

Etter E.-L., Tacitus in der Geistesgeschichte des 16. und 17. Jahrhunderts, Basler Beiträge zur Geschichtswissenschaft 103 (Basel - Stuttgart: 1966).

Kühlmann W., Gelehrtenrepublik und Fürstenstaat. Entwicklung und Kritik des deutschen Späthumanismus in der Literatur des Barockzeitalters (Tübingen: 1982).

van der Lem A. (ed.), De bello Belgico, at http://www.dutchrevolt.leiden.edu (retrieved 8th August 2017).

Maas C., "Was Janus Dousa a Tacitist? Rhetorical and Conceptual Approaches to the Reception of Classical Historiography and its Political Significance", in Enenkel K.A.E. - Laureys M. - Pieper C. (eds.), Discourses of Power. Ideology and Politics in Neo-Latin Literature, Noctes Neolatinae 17 (Hildesheim - Zürich - New York: 2012) 233-248.

Poel M. van der, "Tacitean Elements in Grotius's Narrative of the Capture of Breda (1590) by Stadtholder Maurice, Count of Nassau (Historiae, Book 2)", Grotiana 30 (2009) 207-246.

Vermaseren B.A., De katholieke Nederlandsche geschiedschrijving in de XVIe en XVII ${ }^{e}$ eeuw over den Opstand (Maastricht: 1941).

Waszink J., "Shifting Tacitisms. Style and Composition in Grotius's Annales", Grotiana $29(2008) 85^{-132 .}$ 